\title{
Soybean Products Consumption in the Prevention of Cardiovascular Diseases
}

\author{
Iván Palomoㄹ, Luis Guzmán¹, Elba Leiva¹, Verónica Mujica², \\ Gilda Carrasco ${ }^{3}$, Nora Morgado ${ }^{4}$ and Daniel R. González ${ }^{5}$ \\ ${ }^{1}$ Departamento de Bioquímica Clínica e Inmunología, \\ Facultad de Ciencias de la Salud, Universidad de Talca, , \\ ${ }^{2}$ Escuela de Medicina, Universidad de Talca, \\ ${ }^{3}$ Facultad de Ciencias Agrarias, Universidad de Talca, \\ ${ }^{4}$ Universidad de Los Andes, Santiago, \\ ${ }^{5}$ Departamento de Ciencias Basicas Biomedicas, \\ Facultad de Ciencias de la Salud, Universidad de Talca, Talca,
}

Chile

\section{Introduction}

Soybean is a leguminous plant native to eastern Asia (Liu et al. 2008). Soybean is cultivated worldwide, with the U.S. being responsible for more than $50 \%$ of the world's production of this important food. Soybean grains are rich in protein content (see aminoacids composition, Table 1); therefore constitute a useful source of food. It is consumed as cooked beans, soy sauce, soy milk and tofu (soybean curd). Also, a vegetable oil is obtained from soybeans, rich in polyunsaturated fatty acids. This legume is also a good source of several phytochemicals such as isoflavones and lignans, molecules with antioxidant properties that, among other effects, might help to fight and prevent several pathologies. For these reasons, these compounds have been intensively studied at basic and at the clinical level.

Soybean consumption benefits, especially in the cardiovascular system, have been related to its important protein content, high levels of essential fatty acids, vitamins and minerals. Nevertheless, there has been controversy as to the extent to which soybean is a healthpromoting food. We address some aspects of these issues in this chapter.

\section{Agronomic characteristics of soybean plants}

Soybean (Glycine max L. Merr., subfamily Papilionoidae) is an annual plant that measures up to $1.5 \mathrm{~m}$ tall, with pubescent leaves and pods. The stems are erect and rigid. The root system has as main root which can reach a meter deep, the average being between 40 and 50 centimeters. In its primary and secondary roots, are located a variable number of nodes. One of the characteristic of the root system development is its sensitivity to variations in the supply and distribution of inorganic nutrients in the soil (Forde \& Lorenzo 2001).

Soy leaves are alternate, compound (trifoliate), with the exception of the basal leaves, which are simple. The leaflets have an oval - lanceolate with a green color turning yellow, at maturity stage. Soybean flowers are found in variable number of axillary racemes as 
inflorescences with white or purple colors, depending on the variety. Fruits of soy are pods dehiscent on both sutures (Sánchez A et al. 2004). The pods reach two to three inches in length. Each fruit has three to four seeds, yellow, but there are usually black, green and brown seeds, depending on the variety (Nadal S et al. 2004). The phenologic stages of soybean were described by Ferh and colleagues (Fehr et al. 1971). This scale includes the growth stages of soybean (Table 2). The numbering of the vegetative state is determined by the count of existing nodes on the main stem. Above that, usually there are fully developed leaves. A leaf is already fully developed when the edges of the leaflets of the blade located immediately above are not touching. The reproductive stages are based on flowering, growth of pods and seeds and plant maturity.

\begin{tabular}{|cc|}
\hline Amino acid & g/16 g Nitrogen \\
\hline Isoleucine & 4.54 \\
Leucine & 7.78 \\
Lysine & 6.38 \\
Methionine & 1.26 \\
Cysteine & 1.33 \\
Phenylalanine & 4.94 \\
Tyrosine & 3.14 \\
Threonine & 3.86 \\
Tryptophan & 1.28 \\
Valine & 4.80 \\
Arginine & 7.23 \\
Histidine & 2.53 \\
Alanine & 4.26 \\
Aspartic acid & 11.70 \\
Glutamic acid & 18.70 \\
Glycine & 4.18 \\
Proline & 5.49 \\
Serine & 5.12 \\
\hline
\end{tabular}

Table 1. Amino acid composition of soybeans seeds. Source: Adapted by authors from FAO (1970) and FAO/WHO (1973).

Soybean is a spring-summer crop with a growing period fluctuating between three and seven months. The best zones to cultivate this crop are in temperate regions. This species develops with optimum temperatures between 20 and $30{ }^{\circ} \mathrm{C}$. The vegetative growth is achieved above $10{ }^{\circ} \mathrm{C}$, stopping the development at $4{ }^{\circ} \mathrm{C}$. However, it resists frost of -2 to -4 ${ }^{\circ} \mathrm{C}$. In the sowing season, it requires optimum temperatures that fluctuate between 15 and 18 ${ }^{\circ} \mathrm{C}$ and $25^{\circ} \mathrm{C}$ at flowering stage. For this reason, soybean is established at warmer seasons. The seed maturity is obtained at early and mid-autumn, when the leaves of the soybean crop fall and turn to yellow, and the seeds begin to loss moisture. It is suggested harvesting the crop when the water content of the seed is $13 \%$, the maximum safe moisture level for long-range storage. If the humidity content at harvest is higher, forced-air drying of the seeds will be required prior to storage. Otherwise, the seeds split at mechanical harvest (Lopez Bellido 1988). Soy is a plant sensitive to day length, so it is regarded as a plant with a short-day photoperiod. In relation to moisture, during the growing period, soybeans 
requires at least $300 \mathrm{~mm}$ of water, whether provided by irrigation or rain on those wet rainy temperate zones. However, for good yields it is necessary to apply irrigation of 500 to 700 $\mathrm{mm}$, especially during the period of pod and seed development (Lopez Bellido 1988). Soybeans grow well on most types of soil, but the crop is affected when plants are sown in deep sands with scarce water retention; the optimum soil $\mathrm{pH}$ fluctuates between 6 and 6.5 (Lopez Bellido 1988). This species is able to fix nitrogen through symbiosis with nodulating bacteria in the soil. Literature indicates that up to $50 \%$ of the total nitrogen of the plant may be supplied by the nitrogen fixing mechanism (Berk 1992).

\section{Vegetative stages}

Ve: Emergency cotyledons on the ground surface.

Vc: Cotyledon: unifoliates sufficiently developed so that its edges or sides are not touching.

V1: First Node: fully developed leaves at the node of unifoliates

V2: Second Node: two nodes on main stem with fully developed leaves beginning with the knot unifoliates

Vn $\mathbf{N}^{\mathbf{0}}$ nodes: number of nodes on main stem with fully developed leaves beginning with the knot unifoliates.

\section{Reproductive stages}

R 1 Top Flowering: an open flower at any node on main stem.

R 2 Full Bloom: an open flower at one of the upper main stem nodes with a full developed leaf.

R 3 Top Fruit: pod $5 \mathrm{~mm}$ long in any of the four upper nodes on main stem with a fully developed leaf

R 4 Full Fruit: pods $2 \mathrm{~cm}$ long in any of the four upper nodes on main stem with a fully developed leaf

R 5 Top grain filling: seeds $3 \mathrm{~mm}$ long in a pod in some of the top four nodes on main stem with a fully developed leaf.

R 6 Maximum grain size: the green seed pods are completely fills the cavity of the fruit, in some of the top four nodes on main stem with fully developed leaves.

R 7 Beginning of Maturity: one normal pod on main stem has reached mature color characteristic.

R 8 Commercial Maturity: 95\% of pods with the typical color of maturity

Table 2. Stage of Development Descriptions for Soybeans.

\section{Soybean and cardiovascular diseases}

Cardiovascular diseases are the principal cause of death in the Western population. Among other factors, increased plasma cholesterol levels is an important risk factor for developing atherosclerosis and associated coronary and cerebrovascular diseases (Faergeman 2006; Fernandez \& Webb 2008; Goldstein \& Brown 2009). Control of cholesterol, mainly LDLcholesterol, using pharmacological agents, such as statins, have significantly reduced the risk of cardiovascular diseases (Farmer 1998; Vaughan et al. 2000). However, some side effects associated with statins (Thompson et al. 2003) or others pharmacological therapies, 
have driven the search for natural therapies or alternative approaches for managing hypercholesterolemia, especially in patients with borderline plasma cholesterol (Deng 2009). Food supplements and/or nutraceuticals have become attractive alternatives to prevent or treat hypercholesterolemia and reduce the risk for cardiovascular diseases with few side effects. Soy-based foods, mainly soy protein extract, have been widely associated with beneficial effects on lipoprotein profile, being identified as beneficial for cardiovascular disease (Anderson et al. 1995; Sacks et al. 2006).

Today, numerous epidemiological and clinical studies have linked the consumption of soy based foods with lower incidence of a number of chronic diseases, such as cardiovascular diseases (Anderson et al. 1995; Dewell et al. 2006; Sacks et al. 2006), cancer (Messina et al. 2006), and osteoporosis (Messina \& Messina 2000). However, the mechanisms that explain these effects are not yet fully clarified. Over the past decades, intense research has focused in identifying bioactive components in soy that could be responsible for these effects. Soy protein and isoflavones have been suggested as the major bioactive components in soy and have received considerable attention. In the middle of the 1990s a meta-analysis based in numerous studies in humans showed that soy protein consumption resulted in a significant decrease of $9.3 \%$ of total cholesterol, $12.9 \%$ of LDL (low-density lipoprotein) cholesterol and $10.5 \%$ of triglycerides (Anderson et al. 1995). The effectiveness of the treatment with soy protein was higher in hypercholesterolemic subjects, in other words, it was dependent on the initial plasma cholesterol levels (Anderson et al. 1995; Crouse, III et al. 1999), having only marginal and sometimes null effects in normocholesterolemic subjects. Based mainly in this meta-analysis, the US Food and Drug Administration (FDA) approved the labeling of foods containing soy protein as protective against coronary heart disease. The claim of FDA recommended intake of $25 \mathrm{~g}$ of soy protein per day to reduce risk of developing coronary heart disease (Food and Drug Administration, HHS: final rule, 1999). However, in this health claims, the FDA also stated that there was no sufficient background or evidences to relate isoflavones with the reduction of plasma cholesterol levels.

\subsection{Soy protein hypothesis and LDL cholesterol}

Early evidences linking soy protein consumption and the reduction in cardiovascular risk were obtained in laboratory animals models, where the substitution of animal protein by soy protein extract caused a significantly decrease in plasma cholesterol levels in animals fed with a cholesterol-free diet (Anderson et al. 1995; Carroll 1982; Kritchevsky 1979). The soy protein hypothesis has gained support after the epidemiological observations in Asian countries, where the diet is rich in soy-based foods, with a low incidence of hypercholesterolemia and cardiovascular diseases (Keys 1980). However, the diet is not the only difference between Asian and Western countries. There are important differences in lifestyle that may help to explain the differences in lipoprotein profile and cardiovascular risks. However, the results in human trials have been controversial. The substitution of animal protein with soy protein showed effects only in subjects with increased plasma cholesterol levels, without or only marginal effects in normocholesterolemic or borderline subjects (Crouse, III et al. 1999; Jenkins et al. 2002). Some researchers found that the substitution of almost all animal protein with soy protein resulted in a significantly decrease in plasma cholesterol levels, mainly LDL-cholesterol, but in subjects with severe hypercholesterolemia (Descovich et al. 1980). In 1995, a meta-analysis of numerous studies in humans populations published by Anderson JW (Anderson et al. 1995) reinforced the soy protein hypothesis in subjects with hypercholesterolemia, where a significant decrease in 
total plasma cholesterol and mainly LDL-cholesterol level were observed after replacing animal protein with soy protein. This meta-analysis was the base for the Food and Drugs Administration (FDA) claims published in 1999 in regard to soy consumption. In 2000, the American Heart Association Nutrition Committee published a scientific advisory about soy protein consumption and cardiovascular diseases. This Committee recommended including soy protein in a diet low in saturated fatty acids and cholesterol to reduce the cardiovascular risk (Erdman, Jr. 2000). This Scientific advisory was reviewed in 2006, after evaluating other parameters of cardiovascular risk, such as lipoprotein and blood pressure, and regarding isoflavones as possible responsible of benefits related with cardiovascular diseases (Sacks et al. 2006).

\subsubsection{Isoflavones}

After the publication of the meta-analysis by Anderson and colleagues (Anderson et al. 1995), many well-controlled studies have been designed to explain the soy protein hypothesis with higher specificity and with approaches directed to resolve the molecular mechanisms involved in this effect. Soy protein extracts contain variable amounts of isoflavones called phytoestrogens. Their abundance in soy protein preparations is widely dependent on the methods used to obtain the protein extracts (Erdman, Jr. et al. 2004). The main isoflavones in soy protein extracts include genistein, daidzein, glycitein, their naturally occurring glycosides (genistin, daidzin and glycitin), and malonyl glycosides. Several studies have been performed to establish whether soy protein and/or isoflavones could be responsible for the hipocholesterolemic effects of soy-based diets and therefore, their benefits by cardiovascular health. Some studies used only soy protein and others used purified isoflavones. The results of these numerous experimental trials were analyzed in a meta-analysis and concluded that isoflavones have no impact on plasma cholesterol levels (Jenkins et al. 2002). It is interesting to comment that despite isoflavones did not change significantly the lipoprotein profile or cholesterol levels, the plasma concentration of isoflavones are increased when these biocomponents are included in the diet. Isoflavones are phytoestrogens and have a weak agonistic activity on the mammalian estrogens receptors (ER), due to the similar spatial structure with $17-\beta$-estradiol. Isoflavones have higher binding affinity for the ER $\beta$ receptor than ERa. For this reason, isoflavones are not considered as typical estrogens and have been considered as modulators of ER. In some tissues, isoflavones could be even antagonist o partially agonist of ER. Estrogens and other modulators of these receptors are considered hypolipidemic agents and for this reason, protective for cardiovascular health. However, some modulators are considered inhibitors of the cardioprotective effects of estrogen; in other words, they can increase the cardiovascular risk. Today, still there is not conclusive evidence about isoflavones and their role as modulators of estrogen pathways. Thus, it remains to be determined (Sacks et al. 2006) the results obtained in human:

1) Whether isoflavones are the active ingredients for soy hypocholesterolemic effect; and 2) whether isoflavones act as agonists or antagonists of ER to exert their possible hypocholesterolemic activity.

Recently, a mechanism independent of lipid-lowering effect has been proposed to explain the benefits in reduction of cardiovascular risk (Nagarajan 2010). Atherosclerosis and cardiovascular disease have been widely associated to lipoprotein profile alteration, mainly, cholesterol levels. Recently, pro-inflammatory process has been involved in the etiology of these chronic diseases. Early events that occur in the atherogenesis process involve a complex interaction between activated monocytes and vascular endothelial cells (Palomo et 
al. 2008). When activated, monocytes and vascular endothelial cells react and transmigration occurs, starting a pro-inflammatory process. In the intimae layer, monocytes are transformed into macrophages which take up oxidized LDL-cholesterol to become foam cells. A possible anti-inflammatory role is attributed to soy based diets and this role could explain the anti-atherosclerotic and protective cardiovascular effects of soy products consumption.

\section{Beneficial effect of soybean on the metabolic syndrome}

The metabolic syndrome is a cluster of metabolic alterations associated to insulin resistance (IR), but conceptual differences exist between the currently available definitions (Reaven 2004). Reaven was one of the first to describe this combination as a syndrome that he called IR syndrome or simply "X Syndrome"; later the World Health Organization (WHO) named it Metabolic Syndrome. Aspects of metabolic syndrome include a clustering of cardiovascular risk factors: abdominal obesity, dyslipidemia, blood pressure, insulin resistance, and a proinflammatory state (Borgman \& McErlean 2006).

Current studies estimate that about $50 \%$ of the adult population of the United States is obese (Mokdad et al. 2003). About half of the obese population also suffers from pre-diabetes or metabolic syndrome. Both insulin resistance and obesity are key features of the metabolic syndrome and type 2 diabetes mellitus (Park et al. 2003). One potential mechanism linking obesity and insulin resistance involves the production of hormones or adipokines by adipose tissue. Plasma concentrations of several adipokines, such as leptin, tumor necrosis factor alpha (TNF- $\alpha$ ), and the plasminogen activator-inhibitor 1 (PAI-1), have been associated positively with insulin resistance, whereas adiponectin is negatively associated (Kadowaki et al. 2006; Shoelson et al. 2006). Furthermore, lower plasma concentrations of adiponectin are associated with increased incidence of metabolic syndrome, diabetes, and vascular disease (Lihn et al. 2005; Tan et al. 2004).

The metabolic syndrome is associated with a poorly healthy life style and low consumption of fruits and vegetables; among vegetables we found soybean.

The soybean is the most widely grown and utilized legume in the world. The benefits of soybean consumption are related to its high protein content (Table 1), high levels of essential fatty acids, numerous vitamins and minerals, isoflavones and fibre. Soybean is regarded as equal in protein quality as animal foods. Just one cup of soybeans provides $57.2 \%$ of the daily value for protein for less than 300 calories and only $2.2 \mathrm{~g}$. of saturated fat. In addition, soy protein tends to lower cholesterol levels, while protein consumption from animal sources tends to raise them, since they also include saturated fat and cholesterol. Besides healthy protein, some of the nutritional high points of soybeans include an important amount of well absorbed iron: $49.1 \%$ of the daily value for iron in that same cup of soybeans plus $37.0 \%$ of magnesium and $41.2 \%$ of the daily value for essential omega-3 fatty acids (Morgado 2007).

In addition, soybean products may have a direct impact on the intermediate metabolism. Interestingly, genistein and daidzein, found in soybeans and processed soy protein, have been shown to bind to the peroxisome proliferator-activated receptors (PPAR), particularly to PPARY as well as PPAR a and $\delta$ (Dang et al. 2003; Mezei et al. 2003), suggesting the potential value of isoflavones as a nutritional approach to modulate the action of insulin. PPARs belong to a family of transcription factors of which include three isoforms, PPARa, PPARS ( $\beta$ ) and PPARY (Moore-Carrasco et al. 2008). Soy is the most commonly used botanical in the US, and the FDA has approved a health claim for soy protein and soy-based 
food products, based largely on the evidence that soy consumption improves plasma lipid and lipoprotein concentrations and might reduce risk of coronary heart diseases, and does not appear to increase cancer risk (Wagner et al. 2001).

Wagner and colleagues (Wagner et al. 2008) showed that in male monkeys, consumption of soy protein with its isoflavones increased the insulin secretion following a glucose challenge. There are few studies suggesting that the benefits of soy on carbohydrate metabolism are more evident in females than males. In addition to the binding of isoflavones to PPAR, they have estrogenic activity, binding to both ERa an ER $\beta$, but with greater affinity to ER $\beta$ (Wagner et al. 2001). Genistein is also a tyrosine kinase inhibitor (Akiyama et al. 1987) and high concentrations of genistein may inhibit insulin signalling pathways. However, the potential effects of soy foods in human health remain highly controversial (Erdman, Jr. 2000; Messina et al. 2004; Mezei et al. 2003; Sacks et al. 2006). It has been suggested that many of the health effects of soy may be related to activation of ERa and ER $\beta$, mediated by soy-associated phytoestrogens, especially genistein and daidzein (Badger et al. 2002).

\subsection{Biochemical features of the metabolic syndrome and the impact of soybean}

The progressive increase in obesity, cardiovascular diseases and metabolic syndrome prevalence motivated the National Cholesterol Education Program (NCEP) on its third panel: Treatment of High Blood Cholesterol in Adults (ATP III 2004), to propose clinical criteria to define metabolic syndrome by the presence of three or more of these altered factors: high blood pressure (BP), dyslipidemia (hypertriglyceridemia, low HDLc), high plasmatic glucose and abdominal obesity. A number of cardioprotective benefits have been attributed to dietary isoflavones, contained in soy products, including a reduction in LDL cholesterol, an inhibition of pro-inflammatory cytokines, cell adhesion proteins and inducible nitric oxide production, potential reduction in the susceptibility of the LDL particle to oxidation, inhibition of platelet aggregation and an improvement in vascular reactivity (Rimbach et al. 2008).

With this in mind, it would be expected that high soy consumption would be associated with a lower risk of metabolic syndrome, but little evidence exists regarding the effects of soy consumption on the metabolic syndrome in humans. We will analyze the effect of soybean consumption on each parameter of the metabolic syndrome separately.

\subsubsection{Impact of soy products on blood pressure and endothelial function}

The renin-angiotensin system is one of the most important blood pressure control systems in mammals (Paulis \& Unger 2010). The effect of commercial purified soybean saponin on renin activity and blood pressure was investigated by Hiwatashi and colleagues (Hiwatashi et al. 2010). They found that soybean saponin inhibited renin activity in vitro and that oral administration of soybean saponin at $80 \mathrm{mg} / \mathrm{kg}$ of body weight per day to spontaneously hypertensive rats for 8 weeks significantly decreased blood pressure. In addition, a study investigated the effects of soy protein and soy isoflavones on blood pressure and cholesterol levels in 61 middle-aged men at high risk of developing coronary heart disease in Scotland (Sagara et al. 2004). For five weeks, half the men consumed diets containing at least $20 \mathrm{~g}$ of soy protein and $80 \mathrm{mg}$ of soy isoflavones each day. The effects on blood pressure, cholesterol levels, and urinary excretion of isoflavones were measured, and then compared to those of the other half of the men who were given a placebo diet containing olive oil. Men that consumed soy in their diet presented significant reductions in both diastolic and 
systolic blood pressure. Furthermore, Welty and colleagues (Welty et al. 2007) found that soy nut supplementation significantly reduced systolic and diastolic pressure in all 12 hypertensive women and in 40 of the 48 normotensive women. The order of diets did not affect the response. Hypertensive women (mean baseline systolic BP of $152 \mathrm{~mm} \mathrm{Hg}$ and diastolic BP of $88 \mathrm{~mm} \mathrm{Hg}$ ) had a mean $9.9 \%$ decrease in systolic BP and a $6.8 \%$ decrease in diastolic BP on the soy diet compared with the control diet. Normotensive women (mean systolic pressure of $116 \mathrm{~mm} \mathrm{Hg}$ ) had a $5.2 \%$ decrease in systolic pressure and a $2.9 \%$ decrease in diastolic pressure on the soy diet compared with the control diet. On the other hand, Teede and colleagues found no effect of soy/isoflavones on blood pressure in a study that enrolled 41 hypertensive subjects (Teede et al. 2006).

Regarding endothelial function, it has been reported that the consumption of soy isolated protein improved the flow-induced dilatation in postmenopausal women (Cuevas et al. 2003; Hall et al. 2008), independently of changes in the lipid profile. This effect has been also observed using soybean isoflavones (Colacurci et al. 2005; Lissin et al. 2004).

The mechanisms of action by which soybean products may improve endothelial function include effects on the production of nitric oxide, a key regulator of the cardiovascular function. Soybean products have been shown to increase the levels of endothelial nitric oxide synthase (eNOS). For instance, genistein increased the levels of NOS in spontaneously hypertensive rats (Si \& Liu 2008; Vera et al. 2007) as well as NOS activity (Lin et al. 2011; Si \& Liu 2008). Equol, a metabolite of daidzein produced by intestinal bacteria, has also been shown to activate eNOS and produce vasorelaxation in an acute fashion (Joy et al. 2006).

\subsubsection{Metabolic syndrome dyslipidemia}

In the last decades several publications have shown beneficial effects of soybean products consumption on lipids metabolism.

As mentioned previously, the meta-analysis by Anderson and colleagues (Anderson et al. 1995) indicated that soy protein was effective in lowering plasma cholesterol. Also beneficial results were published in 1998 by Tikkanen and colleagues, showing in six healthy volunteers who consumed soy protein (60 mg isoflavones per day) for 2 weeks, a reduction in LDL oxidation, which is atherogenic (Tikkanen et al. 1998). Later, a similar study confirmed the same in 24 subjects, where dietary supplementation with high-isoflavone soy protein for 17 days prolonged the lag time of copper-induced LDL oxidation compared to a low-isoflavone soy diet and also reduced plasma concentrations of F2-isoprostanes ( marker of lipid peroxidation) (Wiseman et al. 2000). In the same way, Potter in 1998 studied the impact of bioactive components of soy in cardiovascular disease and confirmed that the major components of soybean flour (soy proteins; soy cotyledon fiber and isoflavones) independently decrease serum cholesterol (Potter 1998). A meta-analysis conducted by Ho (Zhan \& Ho 2005) showed that soy protein containing isoflavones significantly reduced serum total cholesterol, LDL cholesterol, and triacylglycerol and significantly increased HDL cholesterol, but the changes were related to the level and duration of intake, and gender and initial serum lipid concentrations of the subjects.

\subsubsection{Glucose metabolism and abdominal obesity}

The effects of soy consumption on glucose metabolism are more controversial than the beneficial effects on lipids, and still remain uncertain since there are many contradictory publications. Clear differences in the carbohydrate profiles were observed following soy intervention, suggesting a soy-induced alteration in energy metabolism (Solanky et al. 2005). 
These results were later supported by metabonomic analyses of $24 \mathrm{~h}$ urine samples from the same individuals and combination of both analyses suggested an inhibition of glycolysis and a general shift in energy metabolism from carbohydrate to lipid metabolism due to isoflavone intervention. In 2007 Ho and colleagues (Ho et al. 2007) studied the long-term effects of soy-derived isoflavones on glycemic control, specifically fasting glucose and found that one-year of soy isoflavone supplementation showed a moderate but significant favorable effect in fasting glucose in postmenopausal Chinese women. On the other hand Liu et al (Liu et al. 2010) published recently an interesting placebo-controlled trial, where they investigated the effects of soy protein and isoflavones on glycemic control and insulin sensitivity: in a 6-months control-case trial with postmenopausal Chinese women, with prediabetes or untreated early diabetes. They concluded that the results did not support the hypothesis that soy protein had favorable effects on glycemic control and insulin sensitivity. The same year, another publication aimed to determine the effects of soy consumption on the components of the metabolic syndrome (Azadbakht et al. 2007) was published. They randomly assigned to 42 postmenopausal women with the metabolic syndrome a control diet (Dietary Approaches to Stop Hypertension, DASH), a soy-protein diet, or a soy-nut diet, each for 8 weeks. Consumption of soy-nut reduced fasting plasma glucose more significantly than the soy-protein or control diet. Soy-nut consumption significantly reduced serum C-peptide concentrations compared with control diet, but consumption of soyprotein did not. The soy-nut regimen also decreased LDL cholesterol more than did the soyprotein period and the control diet.

\section{Soybean effects on hemostasis}

Epidemiological studies suggest that soy consumption is associated, at least in part, with lower incidence of a number of chronic diseases (Anderson et al. 1995; Boyapati et al. 2005). The lower rates of several chronic diseases in Asia, including cardiovascular diseases and certain types of cancer, have been partly attributed to consumption of large quantities of soy foods (Kang et al. 2010; Messina 1995; Wu et al. 1998).

Cardiovascular diseases are leading causes of death worldwide, especially in developed and developing countries. As mentioned before, several risk factors for cardiovascular diseases, including dyslipidemia, hypertension and diabetes mellitus, in large part are influenced by diet (De et al. 2006; Liu et al. 2000).

Epidemiological evidence suggests that a diet rich in fruits and vegetables promotes health, reducing the risk of developing cardiovascular and other types of chronic diseases (Rimm 2002). The contribution in antioxidants from fruits and vegetables is vastly recognized, however, their antithrombotic effects are less known (Torres-Urrutia et al. 2008; TorresUrrutia et al. 2011).

In order to contextualize, we refer to hemostasis, a complex process that prevents the spontaneous loss of blood and stops bleeding caused by damage to the vascular system. This process, traditionally, has been separated into: primary hemostasis, secondary hemostasis (clotting) and fibrinolysis.

\subsection{Primary hemostasis}

This phase includes vasoconstriction and platelet-endothelium interactions. Upon vessel wall injury, rapid and complex interactions between circulating platelets and exposed (sub)endothelial structures occur, resulting in platelet adhesion to the damaged endothelium (Santos et al. 2009). The mechanism by which platelets adhere to the vascular 
wall to achieve hemostasis is well understood, with von Willebrand Factor (vWF)-mediated platelet adhesion being the most important. Another adhesive protein crucially involved in platelet-vessel wall interaction is collagen, that binds to platelet glycoproteins receptors Ia/IIa and GPVI (Clemetson \& Clemetson 2001; Jung \& Moroi 2000).

The roles of platelets include adhesion, secretion (ADP, serotonin and thromboxane A2 (TXA2), and aggregation (interaction between glycoprotein GPIIb-IIIa and fibrinogen). Forming the base of the hemostatic plug, the platelet membrane turns into a phospholipid surface upon activation due to a change in shape. This negatively charged surface is necessary for the assembly of activated coagulation factor complexes which in turn are required for thrombin generation. Platelets form a strong link between the processes of primary and secondary hemostasis.

\subsection{Secondary hemostasis}

The coagulation system corresponds to a cascade of proteolytic activation of plasma factors, typically in two ways, the intrinsic and extrinsic pathways, whose purpose is the formation of fibrin. The fibrin deposit on and between platelets, stabilizes the platelet plug (Palomo et al. 2009).

The coagulation system has three overlapping phases: initiation, amplification and propagation (Hoffman 2003; Hoffman \& Monroe 2007). The coagulation requires the formation of an impermeable platelet and fibrin plug at the site of vessel injury, but it also requires that the powerful procoagulant substances activated in this process remain localized to the site of injury. This control of blood coagulation is accomplished by localizing the procoagulant reactions on specific cell surfaces (Hoffman \& Monroe 2007).

Coagulation in vivo is initiated by the tissue factor. The initiation step is thus localized to the cells that express tissue factor, which are normally found outside the vasculature. A disruption in the vascular wall exposes collagen that causes accumulation and activation of platelets, while exposed tissue factor initiates the process of generating thrombin (Hoffman \& Monroe 2007; Romney \& Glick 2009) . The small quantity of thrombin generated during this phase is the key factor for further thrombin and subsequent fibrin production (Furie \& Furie 2008).

The amplification step sets the stage for subsequent large-scale generation of thrombin in the propagation phase. The small amount of thrombin generated on the tissue factor-bearing cell has several important functions: among others, activation of platelets, activation of the cofactors $\mathrm{V}$ and VIII on the activated platelet surface and activation of factor XI to XIa (Hoffman \& Monroe 2007; Oliver et al. 1999). In the propagation phase, the tenase (FVIIIa/FIXa) and prothrombinase (FVa/FXa) complexes are formed on the platelet surface. The tenase complex activates FX, which then binds to its cofactor, FVa. The prothrombinase complex on the surface of the platelet initiates a burst of thrombin that brings about the conversion of fibrinogen to fibrin. Thrombin produced in this phase also activates factor XIII, which stabilizes the fibrin clot by catalyzing covalent crosslinkage (Hoffman \& Monroe 2007; Schenone et al. 2004; Zimmerman 2007).

\subsection{Fibrinolysis}

This process involves the breakdown of fibrin clots and the restoration of blood flow. The fibrinolytic system activates the process by which a fibrin clot is digested by plasmin to release soluble fibrin degradation products. Plasmin is generated from plasminogen by tissue-type and urinary-type plasminogen activators (tPA and uPA), and the process is 
regulated by the plasmin inhibitor a-2-antiplasmin, plasminogen activator inhibitor (PAI-1) and the Thrombin- Activable Fibrinolysis Inhibitor (TAFI)(Palomo et al. 2009).

\subsection{Antiplatelet activity of soybean products}

Flavonoids The effects of soybean products on platelet aggregation were initially described for genistein (McNicol 1993; Nakashima et al. 1991). In these reports, genistein was able to inhibit platelet activation induced by collagen and TXA2 analogs, but not by thrombin. Daizein, another soy flavonoid that lacks tyrosine kinase inhibitory activity also inhibited the response to collagen and the TXA2 analog, suggesting that these flavonoids inhibit platelet aggregation by competition for the TXA2 receptor (TXA2R) rather than through tyrosine kinase inhibition. These observations were confirmed by other groups (Gottstein et al. 2003; Guerrero et al. 2005; Guerrero et al. 2007). Guerrero and colleagues suggested that this competitive binding was due to structural features of these flavonoids such as the presence of a double bond in $\mathrm{C} 2-\mathrm{C} 3$ and a keto group in $\mathrm{C} 4$. Interestingly, it has been recently described that equol, a metabolite of daidzein, showed higher affinity in binding the TXA2R (Munoz et al. 2009) (Figure 1).

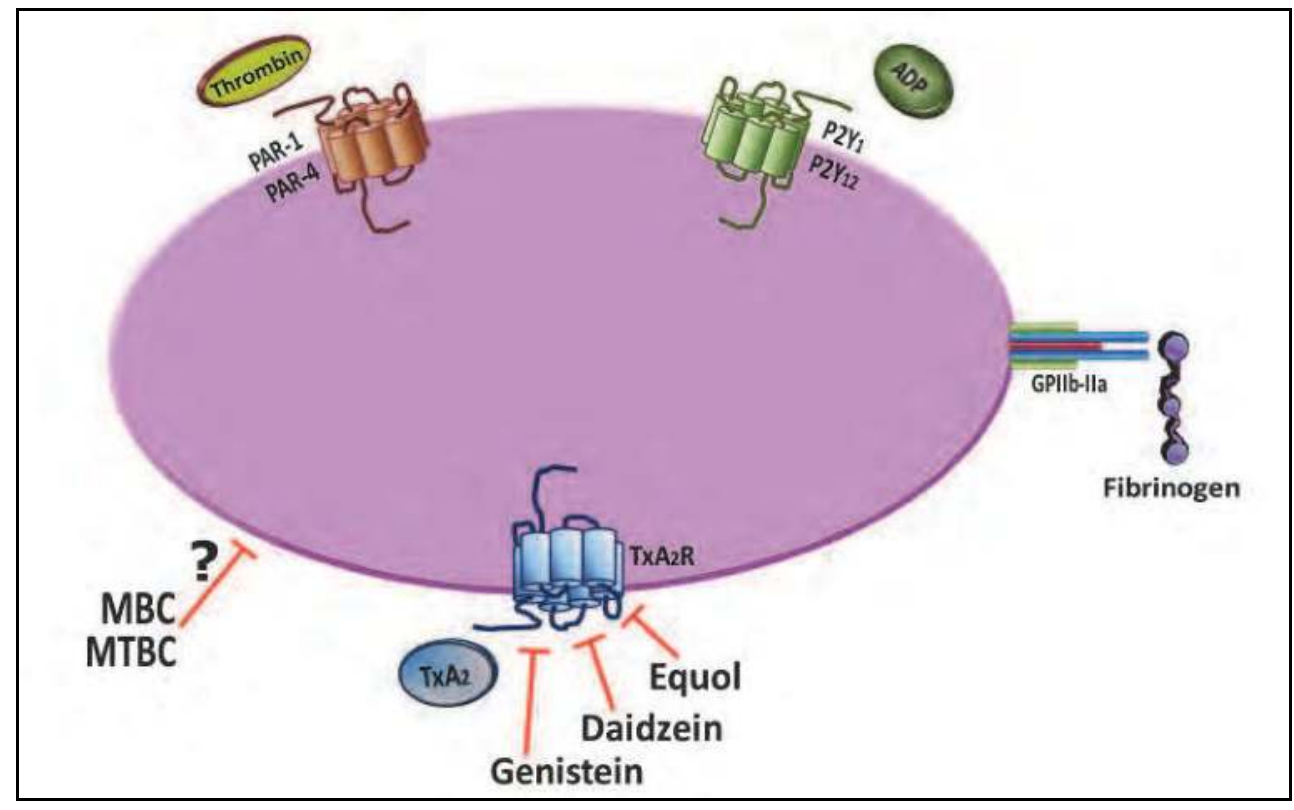

Fig. 1. Antiplatelet effects of soybean products. Equol, daidzein and genistein antagonize the thromboxane A2 receptor. MBC (1-methyl- $\beta$-carboline) and MTBC (-methyl-1,2,3,4tetrahydro- $\beta$-carboline) probably act by affecting the plasma membrane fluidity.

Alkaloids From a extraction of soy sauce, two kinds of components with anti-platelet activity were isolated and structurally identified: 1-methyl-1,2,3,4-tetrahydro- $\beta$-carboline (MTBC) and 1-methyl- $\beta$-carboline (MBC). MTBC shows $\mathrm{IC}_{50 \text { s }}$ ranging from 2.3 to 65.8 $\mu \mathrm{g} / \mathrm{mL}$ for aggregation response induced by epinephrine, platelet-activating factor (PAF), collagen, ADP and thrombin (Tsuchiya et al. 1999). 
Membrane fluidity regulates the platelet function and various membrane-fluidizing agents are known to inhibit platelet aggregation (Kitagawa et al. 1993). Certain $\beta$-carbolines influence the fluidity of model membranes (Peura et al. 1982). The alteration of membrane fluidity may be involved in the antiplatelet effects of MTBC and MBC.

\subsection{Soybean fibrinolytic activity}

Among popular soy foods in Asian countries, natto is a traditional fermented product. Fermented soybeans are prepared using Bacillus subtilis natto (B. natto). Natto extracts are known to include nattokinase, a potent fibrinolytic enzyme having approximately fourtimes stronger activity than plasmin in the clot lysis assay (Fujita et al. 1993). It is composed of 275 amino acid residues (molecular weight, $28 \mathrm{KDa}$ ) and exhibits a high homology with subtilisins (Fujita et al. 1995b). Large-molecule proteins usually are inactive because of nonspecific lysis in the digestive organs. However, in rats after intraduodenal administration, nattokinase was absorbed and decreased fibrinogen levels in plasma (Fujita et al. 1995a; Suzuki et al. 2003). This effect was also observed in humans that received nattokinase, in which the treatment reduced fibrinogen levels as well as those of factor VII and factor VIII (Hsia et al. 2009).

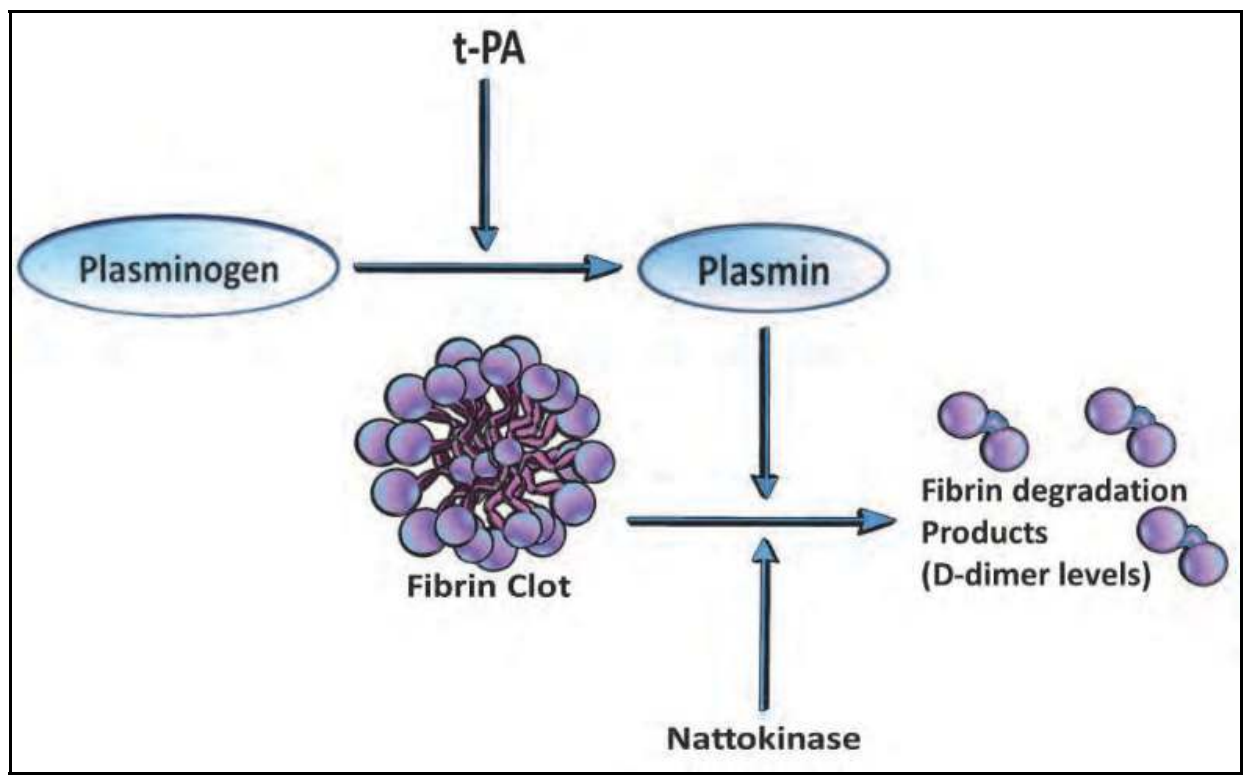

Fig. 2. Fibrinolytic effect of nattokinase, a product of soybean fermentation. tPA, tissue plasminogen activator.

When the proteolytic fragments of fibrin(ogen) were compared with those of plasmin at the same molarity of nattokinase, similar fragments were obtained from the process of cleavage of fibrin(ogen). The cleavage of fibrinogen by nattokinase was three times less efficient than by plasmin as measured from $\mathrm{kcat} / \mathrm{Km}$. However, the cleavage of cross-linked fibrin by nattokinase was six times more efficient than by plasmin. These results suggest that nattokinase is less sensitive to the cleavage by fibrinogen, but is more sensitive to the cleavage by cross-linked fibrin as compared to plasmin (Fujita et al. 1995b). 
Its remarkable thrombolytic efficacy was also shown in a chemically induced thrombosis model, in the common carotid artery of rats in which the endothelial cells of the vessel wall were injured by acetic acid (Fujita et al. 1995a). The thrombolytic activity of nattokinase using this model was compared with fibrino(geno)lytic enzymes, plasmin or elastase. On a molar basis, the recovery of the arterial blood flow with nattokinase, plasmin and elastase were $62.0+/-5.3 \%, 15.8+/-0.7 \%$ and $0 \%$, respectively. These results indicate that the thrombolytic activity of nattokinase is stronger than that of plasmin or elastase in vivo (Fujita et al. 1995a).

\section{Conclusion}

The experimental and epidemiological evidence of the last decades using soy based foods are promising in relation with cardiovascular protection, mainly due to hypocholesterolemic effects. These evidences were consider by FDA, that published claims that recommended soy protein extract as an alternative to reduce blood cholesterol concentrations and increase cardiovascular protection. However, in the last years, several studies have been performed and have been unable to confirm the beneficial effects of soy in blood LDL-cholesterol concentrations and others cardiovascular risk parameters, such as lipoprotein (a) concentrations or blood pressure. Moreover, a very large amount of soy protein, more than protein diary recommended ingest, may lower LDL-cholesterol but this effect depends on initial blood cholesterol concentrations and is modest. The experimental evidences related soy protein more than soy isoflavones as responsible for the observed effects. At present is not possible to discard other components present in soy as responsible by these effects. Neither has been possible to know the molecular mechanism involved in these effects on lipoprotein profile. Today, research is focused on protective effects not associated with lipoprotein profile,such as anti-inflammatory properties, for example, by isoflavones. However, isoflavones are not recommended because there are not conclusive evidences about their role in some cancer types. On the other hand, soy based diets also contain high levels of polyunsaturated fatty acids, fibre and vitamins which could be related with cardiovascular benefits. In conclusion, the evidences obtained from meta-analysis and wellcontrolled studies are not conclusive in relation to hypolipidemic effects of soy as mechanism to explain cardioprotective effects. Recently, studies have begun to propose antiinflammatory properties as possible mechanism to explain protective cardiovascular health. In addition, interesting inhibitory effects of soybean products on platelet activation and aggregation have been shown and suggest that some of the positive effects of soybean products may be mediated by anti-thrombogenic activity.

\section{Acknowledgments}

This work was supported by the Programa de Investigacion en Factores de Riesgo Cardiovascular (PIFRECV), Universidad de Talca, Talca, Chile. http:/ / pifrecv.utalca.cl We thank Mrs. Adriana Treuer for the design of the figures.

\section{References}

Akiyama, T., Ishida, J., Nakagawa, S., Ogawara, H., Watanabe, S., Itoh, N., Shibuya, M. \& Fukami, Y. (1987) Genistein, a specific inhibitor of tyrosine-specific protein kinases. J Biol Chem, 262,pp 5592-5595. 
Anderson, J.W., Johnstone, B.M. \& Cook-Newell, M.E. (1995) Meta-analysis of the effects of soy protein intake on serum lipids. N Engl J Med, 333,pp 276-282.

Azadbakht, L., Kimiagar, M., Mehrabi, Y., Esmaillzadeh, A., Padyab, M., Hu, F.B. \& Willett, W.C. (2007) Soy inclusion in the diet improves features of the metabolic syndrome: a randomized crossover study in postmenopausal women. Am J Clin Nutr, 85,pp 735-741.

Badger, T.M., Ronis, M.J., Hakkak, R., Rowlands, J.C. \& Korourian, S. (2002) The health consequences of early soy consumption. J Nutr, 132,pp 559S-565S.

Berk, Z. (1992) Technology of production of edible flours and protein products from soybeans. In.

Borgman, M. \& McErlean, E. (2006) What is the metabolic syndrome? Prediabetes and cardiovascular risk. J Cardiovasc Nurs, 21,pp 285-290.

Boyapati, S.M., Shu, X.O., Ruan, Z.X., Dai, Q., Cai, Q., Gao, Y.T. \& Zheng, W. (2005) Soyfood intake and breast cancer survival: a followup of the Shanghai Breast Cancer Study. Breast Cancer Res Treat, 92,pp 11-17.

Carroll, K.K. (1982) Hypercholesterolemia and atherosclerosis: effects of dietary protein. Fed Proc, 41,pp 2792-2796.

Clemetson, K.J. \& Clemetson, J.M. (2001) Platelet collagen receptors. Thromb Haemost, 86,pp 189-197.

Colacurci, N., Chiantera, A., Fornaro, F., de, N., V, Manzella, D., Arciello, A., Chiantera, V., Improta, L. \& Paolisso, G. (2005) Effects of soy isoflavones on endothelial function in healthy postmenopausal women. Menopause, 12,pp 299-307.

Crouse, J.R., III, Morgan, T., Terry, J.G., Ellis, J., Vitolins, M. \& Burke, G.L. (1999) A randomized trial comparing the effect of casein with that of soy protein containing varying amounts of isoflavones on plasma concentrations of lipids and lipoproteins. Arch Intern Med, 159,pp 2070-2076.

Cuevas, A.M., Irribarra, V.L., Castillo, O.A., Yanez, M.D. \& Germain, A.M. (2003) Isolated soy protein improves endothelial function in postmenopausal hypercholesterolemic women. Eur J Clin Nutr, 57,pp 889-894.

Dang, Z.C., Audinot, V., Papapoulos, S.E., Boutin, J.A. \& Lowik, C.W. (2003) Peroxisome proliferator-activated receptor gamma (PPARgamma) as a molecular target for the soy phytoestrogen genistein. J Biol Chem, 278,pp 962-967.

De, V.E., de, N.J., de Vries, N.K. \& Brug, J. (2006) The Transtheoretical model for fruit, vegetable and fish consumption: associations between intakes, stages of change and stage transition determinants. Int J Behav Nutr Phys Act, 3,pp pp13.

Deng, R. (2009) Food and food supplements with hypocholesterolemic effects. Recent Pat Food Nutr Agric, 1,pp 15-24.

Descovich, G.C., Ceredi, C., Gaddi, A., Benassi, M.S., Mannino, G., Colombo, L., Cattin, L., Fontana, G., Senin, U., Mannarino, E., Caruzzo, C., Bertelli, E., Fragiacomo, C., Noseda, G., Sirtori, M. \& Sirtori, C.R. (1980) Multicentre study of soybean protein diet for outpatient hyper-cholesterolaemic patients. Lancet, 2,pp 709-712.

Dewell, A., Hollenbeck, P.L. \& Hollenbeck, C.B. (2006) Clinical review: a critical evaluation of the role of soy protein and isoflavone supplementation in the control of plasma cholesterol concentrations. J Clin Endocrinol Metab, 91,pp 772-780. 
Erdman, J.W., Jr. (2000) AHA Science Advisory: Soy protein and cardiovascular disease: A statement for healthcare professionals from the Nutrition Committee of the AHA. Circulation, 102,pp 2555-2559.

Erdman, J.W., Jr., Badger, T.M., Lampe, J.W., Setchell, K.D. \& Messina, M. (2004) Not all soy products are created equal: caution needed in interpretation of research results. $J$ Nutr, 134,pp 1229S-1233S.

Faergeman, O. (2006) Introduction: Apolipoproteins and guidelines for prevention of cardiovascular disease. J Intern Med, 259,pp 434-436.

Farmer, J.A. (1998) Aggressive lipid therapy in the statin era. Prog Cardiovasc Dis, 41,pp 7194.

Fehr, W.R., Caviness, C.E., Burmood, J.T. \& Penington, D.S. (1971) Stage of development descriptions for soybeans, Glycine max (L.) Merrill. Crop Science, 11,pp 929-931.

Fernandez, M.L. \& Webb, D. (2008) The LDL to HDL cholesterol ratio as a valuable tool to evaluate coronary heart disease risk. J Am Coll Nutr, 27,pp 1-5.

Forde, B. \& Lorenzo, H. (2001) The nutritional control of root development. Plant and Soil, 232,pp 51-68.0032-079X.

Fujita, M., Hong, K., Ito, Y., Fujii, R., Kariya, K. \& Nishimuro, S. (1995a) Thrombolytic effect of nattokinase on a chemically induced thrombosis model in rat. Biol Pharm Bull, 18,pp 1387-1391.

Fujita, M., Ito, Y., Hong, K. \& Nishimuro, S. (1995b) Characterization of NattokinaseDegraded Products from Human Fibrinogen Or Cross-Linked Fibrin. Fibrinolysis, 9,pp 157-164.0268-9499.

Fujita, M., Nomura, K., Hong, K., Ito, Y., Asada, A. \& Nishimuro, S. (1993) Purification and characterization of a strong fibrinolytic enzyme (nattokinase) in the vegetable cheese natto, a popular soybean fermented food in Japan. Biochem Biophys Res Commun, 197,pp 1340-1347.

Furie, B. \& Furie, B.C. (2008) Mechanisms of thrombus formation. N Engl J Med, 359,pp 938949.

Goldstein, J.L. \& Brown, M.S. (2009) The LDL receptor. Arterioscler Thromb Vasc Biol, 29,pp 431-438.

Gottstein, N., Ewins, B.A., Eccleston, C., Hubbard, G.P., Kavanagh, I.C., Minihane, A.M., Weinberg, P.D. \& Rimbach, G. (2003) Effect of genistein and daidzein on platelet aggregation and monocyte and endothelial function. Br J Nutr, 89,pp 607-616.

Guerrero, J.A., Lozano, M.L., Castillo, J., Benavente-Garcia, O., Vicente, V. \& Rivera, J. (2005) Flavonoids inhibit platelet function through binding to the thromboxane A2 receptor. J Thromb Haemost, 3,pp 369-376.

Guerrero, J.A., Navarro-Nunez, L., Lozano, M.L., Martinez, C., Vicente, V., Gibbins, J.M. \& Rivera, J. (2007) Flavonoids inhibit the platelet $\operatorname{TxA}(2)$ signalling pathway and antagonize $\mathrm{TxA}(2)$ receptors $(\mathrm{TP})$ in platelets and smooth muscle cells. Br J Clin Pharmacol, 64,pp 133-144.

Hall, W.L., Formanuik, N.L., Harnpanich, D., Cheung, M., Talbot, D., Chowienczyk, P.J. \& Sanders, T.A. (2008) A meal enriched with soy isoflavones increases nitric oxidemediated vasodilation in healthy postmenopausal women. J Nutr, 138,pp 12881292.

Hiwatashi, K., Shirakawa, H., Hori, K., Yoshiki, Y., Suzuki, N., Hokari, M., Komai, M. \& Takahashi, S. (2010) Reduction of blood pressure by soybean saponins, renin 
inhibitors from soybean, in spontaneously hypertensive rats. Biosci Biotechnol Biochem, 74,pp 2310-2312.

Ho, S.C., Chen, Y.M., Ho, S.S. \& Woo, J.L. (2007) Soy isoflavone supplementation and fasting serum glucose and lipid profile among postmenopausal Chinese women: a doubleblind, randomized, placebo-controlled trial. Menopause, 14,pp 905-912.

Hoffman, M. (2003) Remodeling the blood coagulation cascade. J Thromb Thrombolysis, 16,pp $17-20$.

Hoffman, M. \& Monroe, D.M. (2007) Coagulation 2006: a modern view of hemostasis. Hematol Oncol Clin North Am, 21,pp 1-11.

Hsia, C.H., Shen, M.C., Lin, J.S., Wen, Y.K., Hwang, K.L., Cham, T.M. \& Yang, N.C. (2009) Nattokinase decreases plasma levels of fibrinogen, factor VII, and factor VIII in human subjects. Nutr Res, 29,pp 190-196.

Jenkins, D.J., Kendall, C.W., Jackson, C.J., Connelly, P.W., Parker, T., Faulkner, D., Vidgen, E., Cunnane, S.C., Leiter, L.A. \& Josse, R.G. (2002) Effects of high- and lowisoflavone soyfoods on blood lipids, oxidized LDL, homocysteine, and blood pressure in hyperlipidemic men and women. Am J Clin Nutr, 76,pp 365-372.

Joy, S., Siow, R.C., Rowlands, D.J., Becker, M., Wyatt, A.W., Aaronson, P.I., Coen, C.W., Kallo, I., Jacob, R. \& Mann, G.E. (2006) The isoflavone Equol mediates rapid vascular relaxation: $\mathrm{Ca} 2+$-independent activation of endothelial nitric-oxide synthase/Hsp90 involving ERK1/2 and Akt phosphorylation in human endothelial cells. J Biol Chem, 281,pp 27335-27345.

Jung, S.M. \& Moroi, M. (2000) Activation of the platelet collagen receptor integrin alpha(2)beta(1): its mechanism and participation in the physiological functions of platelets. Trends Cardiovasc Med, 10,pp 285-292.

Kadowaki, T., Yamauchi, T., Kubota, N., Hara, K., Ueki, K. \& Tobe, K. (2006) Adiponectin and adiponectin receptors in insulin resistance, diabetes, and the metabolic syndrome. J Clin Invest, 116,pp 1784-1792.

Kang, J., Badger, T.M., Ronis, M.J. \& Wu, X. (2010) Non-isoflavone phytochemicals in soy and their health effects. J Agric Food Chem, 58,pp 8119-8133.

Keys, A. (1980) Seven Countries: A Multivariate Analysis of Death and Coronary Heart Disease. Harvard University Press: Cambridge, Massachusetts.

Kitagawa, S., Orinaka, M. \& Hirata, H. (1993) Depth-dependent change in membrane fluidity by phenolic compounds in bovine platelets and its relationship with their effects on aggregation and adenylate cyclase activity. Biochim Biophys Acta, 1179,pp 277-282.

Kritchevsky, D. (1979) Vegetable protein and atherosclerosis. J Am Oil Chem Soc, 56,pp 135140.

Lihn, A.S., Pedersen, S.B. \& Richelsen, B. (2005) Adiponectin: action, regulation and association to insulin sensitivity. Obes Rev, 6,pp 13-21.

Lin, A.H., Leung, G.P., Leung, S.W., Vanhoutte, P.M. \& Man, R.Y. (2011) Genistein enhances relaxation of the spontaneously hypertensive rat aorta by transactivation of epidermal growth factor receptor following binding to membrane estrogen receptors-alpha and activation of a $G$ protein-coupled, endothelial nitric oxide synthase-dependent pathway. Pharmacol Res, 63,pp 181-189. 
Lissin, L.W., Oka, R., Lakshmi, S. \& Cooke, J.P. (2004) Isoflavones improve vascular reactivity in post-menopausal women with hypercholesterolemia. Vasc Med, 9,pp 26-30.

Liu, S., Manson, J.E., Lee, I.M., Cole, S.R., Hennekens, C.H., Willett, W.C. \& Buring, J.E. (2000) Fruit and vegetable intake and risk of cardiovascular disease: the Women's Health Study. Am J Clin Nutr, 72,pp 922-928.

Liu, X., Jin, H., Wang, G.H. \& Herbert, S.J. (2008) Soybean yield physiology and development of high-yielding practices in Northeast China. Field Crops Research, 105,pp 157-171.0378-4290.

Liu, Z.M., Chen, Y.M., Ho, S.C., Ho, Y.P. \& Woo, J. (2010) Effects of soy protein and isoflavones on glycemic control and insulin sensitivity: a 6-mo double-blind, randomized, placebo-controlled trial in postmenopausal Chinese women with prediabetes or untreated early diabetes. Am J Clin Nutr, 91,pp 1394-1401.

Lopez Bellido, L. (1988) La soja en España. In: Venturini, J.P. \& Amaducci, T., La Soja. Mundi-Prensa: Madrid.

McNicol, A. (1993) The effects of genistein on platelet function are due to thromboxane receptor antagonism rather than inhibition of tyrosine kinase. Prostaglandins Leukot Essent Fatty Acids, 48,pp 379-384.

Messina, M. (1995) Modern applications for an ancient bean: soybeans and the prevention and treatment of chronic disease. J Nutr, 125,pp 567S-569S.

Messina, M., Erdman, J., Jr. \& Setchell, K.D. (2004) Introduction to and perspectives from the Fifth International Symposium on the Role of Soy in Preventing and Treating Chronic Disease. J Nutr, 134,pp 1205S-1206S.

Messina, M., McCaskill-Stevens, W. \& Lampe, J.W. (2006) Addressing the soy and breast cancer relationship: review, commentary, and workshop proceedings. J Natl Cancer Inst, 98,pp 1275-1284.

Messina, M. \& Messina, V. (2000) Soyfoods, soybean isoflavones, and bone health: a brief overview. J Ren Nutr, 10,pp 63-68.

Mezei, O., Banz, W.J., Steger, R.W., Peluso, M.R., Winters, T.A. \& Shay, N. (2003) Soy isoflavones exert antidiabetic and hypolipidemic effects through the PPAR pathways in obese Zucker rats and murine RAW 264.7 cells. J Nutr, 133,pp 12381243.

Mokdad, A.H., Ford, E.S., Bowman, B.A., Dietz, W.H., Vinicor, F., Bales, V.S. \& Marks, J.S. (2003) Prevalence of obesity, diabetes, and obesity-related health risk factors, 2001. JAMA, 289,pp 76-79.

Moore-Carrasco, R., Bustamante, M.P., Guerra, O.G., Madariaga, E.L., Escudero, V.M., Arellano, C.A. \& Palomo, I. (2008) Peroxisome proliferator-activated receptors: Targets for the treatment of metabolic illnesses (Review). Molecular Medicine Reports, 1,pp 317-324.1791-2997.

Morgado, N. (2007) Acidos Grasos y Dieta Mediterranea. In: Palomo, I., Leiva, E. \& Vasquez, M., Dieta Mediterranea: Prevencion de las Enfermedades Cardiovasculares. Editorial Universidad de Talca: Talca, 95-101.

Munoz, Y., Garrido, A. \& Valladares, L. (2009) Equol is more active than soy isoflavone itself to compete for binding to thromboxane $\mathrm{A}(2)$ receptor in human platelets. Thromb Res, 123,pp 740-744. 
Nadal S, Moreno MT \& Cubero, J. (2004) Soja (Glycine max (L.) Merril). Las leguminosas grano en la agricultura moderna. Ediciones Mundi-Prensa: Madrid, 318.

Nagarajan, S. (2010) Mechanisms of anti-atherosclerotic functions of soy-based diets. J Nutr Biochem, 21,pp 255-260.

Nakashima, S., Koike, T. \& Nozawa, Y. (1991) Genistein, a protein tyrosine kinase inhibitor, inhibits thromboxane A2-mediated human platelet responses. Mol Pharmacol, 39,pp 475-480.

Oliver, J.A., Monroe, D.M., Roberts, H.R. \& Hoffman, M. (1999) Thrombin activates factor XI on activated platelets in the absence of factor XII. Arterioscler Thromb Vasc Biol, 19,pp 170-177.

Palomo, I., Fardella, P. \& Pereira, J. (2009) Sistema de la Coagulacion y Sistema Fibrinolitico. In: Palomo, I., Pereira, J. \& Palma, J., Hematologia: Fisiopatologia y Diagnostico. Editorial Universidad de Talca: Talca, 494-510.

Palomo, I., Toro, C. \& Alarcon, M. (2008) The role of platelets in the pathophysiology of atherosclerosis (Review). Molecular Medicine Reports, 1,pp 179-184.1791-2997.

Park, Y.W., Zhu, S., Palaniappan, L., Heshka, S., Carnethon, M.R. \& Heymsfield, S.B. (2003) The metabolic syndrome: prevalence and associated risk factor findings in the US population from the Third National Health and Nutrition Examination Survey, 1988-1994. Arch Intern Med, 163,pp 427-436.

Paulis, L. \& Unger, T. (2010) Novel therapeutic targets for hypertension. Nat Rev Cardiol, 7,pp 431-441.

Peura, P., Mackenzie, P., Koivusaari, U. \& Lang, M. (1982) Increased fluidity of a model membrane caused by tetrahydro-beta-carbolines. Mol Pharmacol, 22,pp 721-724.

Potter, S.M. (1998) Soy protein and cardiovascular disease: the impact of bioactive components in soy. Nutr Rev, 56,pp 231-235.

Reaven, G.M. (2004) Insulin resistance, cardiovascular disease, and the metabolic syndrome: how well do the emperor's clothes fit? Diabetes Care, 27,pp 1011-1012.

Rimbach, G., Boesch-Saadatmandi, C., Frank, J., Fuchs, D., Wenzel, U., Daniel, H., Hall, W.L. \& Weinberg, P.D. (2008) Dietary isoflavones in the prevention of cardiovascular disease--a molecular perspective. Food Chem Toxicol, 46,pp 1308-1319.

Rimm, E.B. (2002) Fruit and vegetables--building a solid foundation. Am J Clin Nutr, 76,pp 12.

Romney, G. \& Glick, M. (2009) An updated concept of coagulation with clinical implications. J Am Dent Assoc, 140,pp 567-574.

Sacks, F.M., Lichtenstein, A., Van, H.L., Harris, W., Kris-Etherton, P. \& Winston, M. (2006) Soy protein, isoflavones, and cardiovascular health: a summary of a statement for professionals from the american heart association nutrition committee. Arterioscler Thromb Vasc Biol, 26,pp 1689-1692.

Sagara, M., Kanda, T., NJelekera, M., Teramoto, T., Armitage, L., Birt, N., Birt, C. \& Yamori, Y. (2004) Effects of dietary intake of soy protein and isoflavones on cardiovascular disease risk factors in high risk, middle-aged men in Scotland. J Am Coll Nutr, 23,pp 85-91.

Sánchez A, Kirchner FR, López E \& Usami CR. (2004) Área: Producción vegetal. Cultivos oleaginosos. Manuales para educación agropecuaria. Editorial Trillas SA: México D.F., 72. 
Santos, M.T., Arande, E., Valles, J. \& Palomo, I. (2009) Hemostasia Primaria. In: Palomo, I., Pereira, J. \& Palma, J., Hematologia: Fisiopatologia y Diagnostico. Editorial Universidad de Talca: Talca, 459-462.

Schenone, M., Furie, B.C. \& Furie, B. (2004) The blood coagulation cascade. Curr Opin Hematol, 11,pp 272-277.

Shoelson, S.E., Lee, J. \& Goldfine, A.B. (2006) Inflammation and insulin resistance. J Clin Invest, 116,pp 1793-1801.

$\mathrm{Si}, \mathrm{H}$. \& Liu, D. (2008) Genistein, a soy phytoestrogen, upregulates the expression of human endothelial nitric oxide synthase and lowers blood pressure in spontaneously hypertensive rats. J Nutr, 138,pp 297-304.

Solanky, K.S., Bailey, N.J., Beckwith-Hall, B.M., Bingham, S., Davis, A., Holmes, E., Nicholson, J.K. \& Cassidy, A. (2005) Biofluid 1H NMR-based metabonomic techniques in nutrition research - metabolic effects of dietary isoflavones in humans. J Nutr Biochem, 16,pp 236-244.

Suzuki, Y., Kondo, K., Matsumoto, Y., Zhao, B.Q., Otsuguro, K., Maeda, T., Tsukamoto, Y., Urano, T. \& Umemura, K. (2003) Dietary supplementation of fermented soybean, natto, suppresses intimal thickening and modulates the lysis of mural thrombi after endothelial injury in rat femoral artery. Life Sci, 73,pp 1289-1298.

Tan, K.C., Xu, A., Chow, W.S., Lam, M.C., Ai, V.H., Tam, S.C. \& Lam, K.S. (2004) Hypoadiponectinemia is associated with impaired endothelium-dependent vasodilation. J Clin Endocrinol Metab, 89,pp 765-769.

Teede, H.J., Giannopoulos, D., Dalais, F.S., Hodgson, J. \& McGrath, B.P. (2006) Randomised, controlled, cross-over trial of soy protein with isoflavones on blood pressure and arterial function in hypertensive subjects. J Am Coll Nutr, 25,pp 533-540.

Thompson, P.D., Clarkson, P. \& Karas, R.H. (2003) Statin-associated myopathy. JAMA, 289,pp 1681-1690.

Tikkanen, M.J., Wahala, K., Ojala, S., Vihma, V. \& Adlercreutz, H. (1998) Effect of soybean phytoestrogen intake on low density lipoprotein oxidation resistance. Proc Natl Acad Sci U S A, 95,pp 3106-3110.

Torres-Urrutia, C., Guzman, L., Moore-Carrasco, R. \& Palomo, I. (2008) Antithrombotic effect, a not well known characteristic of fruits and vegetables. Revista Chilena de Nutrición, 31,pp 10-17.0716-1549.

Torres-Urrutia, C., Guzman, L., Schmeda-Hirschmann, G., Moore-Carrasco, R., Alarcon, M., Astudillo, L., Gutierrez, M., Carrasco, G., Yuri, J.A., Aranda, E. \& Palomo, I. (2011) Antiplatelet, anticoagulant, and fibrinolytic activity in vitro of extracts from selected fruits and vegetables. Blood Coagul Fibrinolysis

Tsuchiya, H., Sato, M. \& Watanabe, I. (1999) Antiplatelet activity of soy sauce as functional seasoning. J Agric Food Chem, 47,pp 4167-4174.

Vaughan, C.J., Gotto, A.M., Jr. \& Basson, C.T. (2000) The evolving role of statins in the management of atherosclerosis. J Am Coll Cardiol, 35,pp 1-10.

Vera, R., Sanchez, M., Galisteo, M., Villar, I.C., Jimenez, R., Zarzuelo, A., Perez-Vizcaino, F. \& Duarte, J. (2007) Chronic administration of genistein improves endothelial dysfunction in spontaneously hypertensive rats: involvement of eNOS, caveolin and calmodulin expression and NADPH oxidase activity. Clin Sci (Lond), 112,pp 183-191. 
Wagner, J.D., Anthony, M.S. \& Cline, J.M. (2001) Soy phytoestrogens: research on benefits and risks. Clin Obstet Gynecol, 44,pp 843-852.

Wagner, J.D., Zhang, L., Shadoan, M.K., Kavanagh, K., Chen, H., Tresnasari, K., Kaplan, J.R. \& Adams, M.R. (2008) Effects of soy protein and isoflavones on insulin resistance and adiponectin in male monkeys. Metabolism, 57,pp ppS24-S31.

Welty, F.K., Lee, K.S., Lew, N.S. \& Zhou, J.R. (2007) Effect of soy nuts on blood pressure and lipid levels in hypertensive, prehypertensive, and normotensive postmenopausal women. Arch Intern Med, 167,pp 1060-1067.

Wiseman, H., O'Reilly, J.D., Adlercreutz, H., Mallet, A.I., Bowey, E.A., Rowland, I.R. \& Sanders, T.A. (2000) Isoflavone phytoestrogens consumed in soy decrease F(2)isoprostane concentrations and increase resistance of low-density lipoprotein to oxidation in humans. Am J Clin Nutr, 72,pp 395-400.

Wu, A.H., Ziegler, R.G., Nomura, A.M., West, D.W., Kolonel, L.N., Horn-Ross, P.L., Hoover, R.N. \& Pike, M.C. (1998) Soy intake and risk of breast cancer in Asians and Asian Americans. Am J Clin Nutr, 68,pp 1437S-1443S.

Zhan, S. \& Ho, S.C. (2005) Meta-analysis of the effects of soy protein containing isoflavones on the lipid profile. Am J Clin Nutr, 81,pp 397-408.

Zimmerman, L.H. (2007) Causes and consequences of critical bleeding and mechanisms of blood coagulation. Pharmacotherapy, 27,pp 45S-56S. 


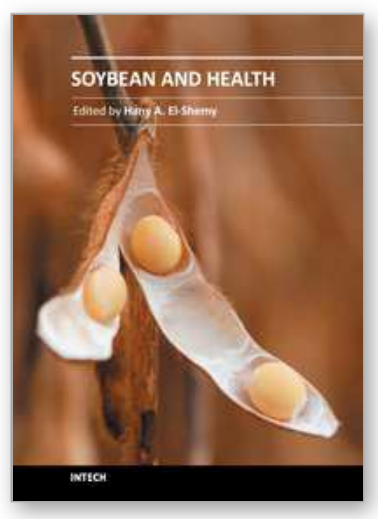

\author{
Soybean and Health \\ Edited by Prof. Hany El-Shemy
}

ISBN 978-953-307-535-8

Hard cover, 502 pages

Publisher InTech

Published online 12, September, 2011

Published in print edition September, 2011

Worldwide, soybean seed proteins represent a major source of amino acids for human and animal nutrition. Soybean seeds are an important and economical source of protein in the diet of many developed and developing countries. Soy is a complete protein, and soy-foods are rich in vitamins and minerals. Soybean protein provides all the essential amino acids in the amounts needed for human health. Recent research suggests that soy may also lower risk of prostate, colon and breast cancers as well as osteoporosis and other bone health problems, and alleviate hot flashes associated with menopause. This volume is expected to be useful for student, researchers and public who are interested in soybean.

\title{
How to reference
}

In order to correctly reference this scholarly work, feel free to copy and paste the following:

Iván Palomo, Luis Guzmán, Elba Leiva, Verónica Mujica, Gilda Carrasco, Nora Morgado and Daniel R. González (2011). Soybean Products Consumption in the Prevention of Cardiovascular Diseases, Soybean and Health, Prof. Hany EI-Shemy (Ed.), ISBN: 978-953-307-535-8, InTech, Available from:

http://www.intechopen.com/books/soybean-and-health/soybean-products-consumption-in-the-prevention-ofcardiovascular-diseases

\section{INTECH}

open science | open minds

\section{InTech Europe}

University Campus STeP Ri

Slavka Krautzeka 83/A

51000 Rijeka, Croatia

Phone: +385 (51) 770447

Fax: +385 (51) 686166

www.intechopen.com

\section{InTech China}

Unit 405, Office Block, Hotel Equatorial Shanghai

No.65, Yan An Road (West), Shanghai, 200040, China

中国上海市延安西路65号上海国际贵都大饭店办公楼 405 单元

Phone: +86-21-62489820

Fax: $+86-21-62489821$ 
(C) 2011 The Author(s). Licensee IntechOpen. This chapter is distributed under the terms of the Creative Commons Attribution-NonCommercialShareAlike-3.0 License, which permits use, distribution and reproduction for non-commercial purposes, provided the original is properly cited and derivative works building on this content are distributed under the same license. 